\title{
An Investigation into the Metal Potentials across Bidkhan Area Based on Economic Geological Studies
}

\author{
Alireza Ashofteh', Ahmad Adib ${ }^{2}$ \\ ${ }^{1}$ Young Researchers and Elite Club, Science and Research Branch, Islamic Azad University, Tehran, Iran \\ ${ }^{2}$ Mining Engineering Department, Islamic Azad University South Tehran Branch, Tehran, Iran \\ Email:st_a_ashofteh@azad.ac.ir, adib@azad.ac.ir
}

Received 8 September 2015; accepted 30 October 2015; published 3 November 2015

Copyright (C) 2015 by authors and Scientific Research Publishing Inc.

This work is licensed under the Creative Commons Attribution International License (CC BY). http://creativecommons.org/licenses/by/4.0/

(c) (i) Open Access

\begin{abstract}
The study area is situated in the NW-trending Urumieh-Dokhtar volcanic belt evolved during Arabia-Eurasia convergence. At the center of Bidkhan, there is an area of approximately $10 \mathbf{~ k m}^{2}$, which is an altered volcanic-intrusive complex. Effort will be made to provide a more accurate picture of the alteration landscape across Bidkhan on the map. The purpose is to clarify how alteration at several points has occurred so as to understand the features of alteration. The altered area is covered by younger events, which have in turn gone through alteration covering another type of alteration on the lower layer. Studies show that there are no traces of either metallic or non-metallic mining activities in the region. The only notable point is the rare remnants of slags spread sporadically across one spot of the region. It is unknown where the small pieces of slag about $10 \mathrm{~cm} \times 10 \mathrm{~cm}$ originate from and which mineralization is involved. It seems that due to the expansion of copper mineralization at Bidkhan, the slags are produced from the copper smelting.
\end{abstract}

\section{Keywords}

Bidkhan, Economic Geological, Alteration, Fault

\section{Introduction}

Bidkhan has been extremely fractured and crushed at the surface range, where the major faults have been laterally displaced or slid by minor strike-slip and oblique-slip faults. Moreover, the joints are important structural elements visible at high density throughout Bidkhan. They are more abundant than the large fractured joints resulted from tensile stresses, so that the effects of fluid solutions can be found across the entire mono-directional 
and uniform joints, where Bidkhan 4 project was implemented. Such a general trend for major faults is N-S. The fundamental trend involves the quartet group at Bidkhan stretching from north to south, along which other major faults have been extended. In the space between the major faults with reverse opaque-slip mechanism, there are minor faults at high density generally opaque-slip from both types right-slip and left-slip [1] [2].

\section{Evaluation of Altered Spots with Mineralization Potentials}

\subsection{Point N29 37 31.4 E56 3102.1}

This point is an example of argillic, propylitic supergene, i.e. argillic alteration. Ghaleh-hadi is a large, long waterway stretching approximately E, SE - W, NW, which ends at Bidkhan's main valley. The area has been covered by volcanic and volcanoclastic outcrops, where the andesitic dikes are visible (Figure 1). This point is in fact near an aplitic mass contact (Bidkhan Central Complex Contact) with volcanic outcrops. Samples were taken from the termination of Ghaleh-hadi valley, which is an andesitic-dacitic tuff attributed to volcanic activities across the region, indicating the transformation into clay minerals and silicification where there are visible patches in red and red-brown due to pyrite alteration. The area surrounding this spot displayed on the alteration map is an area with propylitic, argillic and albite alterations (Table 1).

In the above table, Au has been measured in $\mathrm{Fe}_{2} \mathrm{O}_{3}$, ppb in percentage, and other elements in ppm. These samples can indicate argillic-illite alteration. Such alteration is associated with epithermal mineralization or in case of marginal and upper parts with intrusive bodies. The outcrops surrounding the spot are similar in one common feature which is sulfide veinlets (Figure 2). However, there was another sample with 50\% kaolinite demonstrating a system that created such an intensity of kaolinitation.
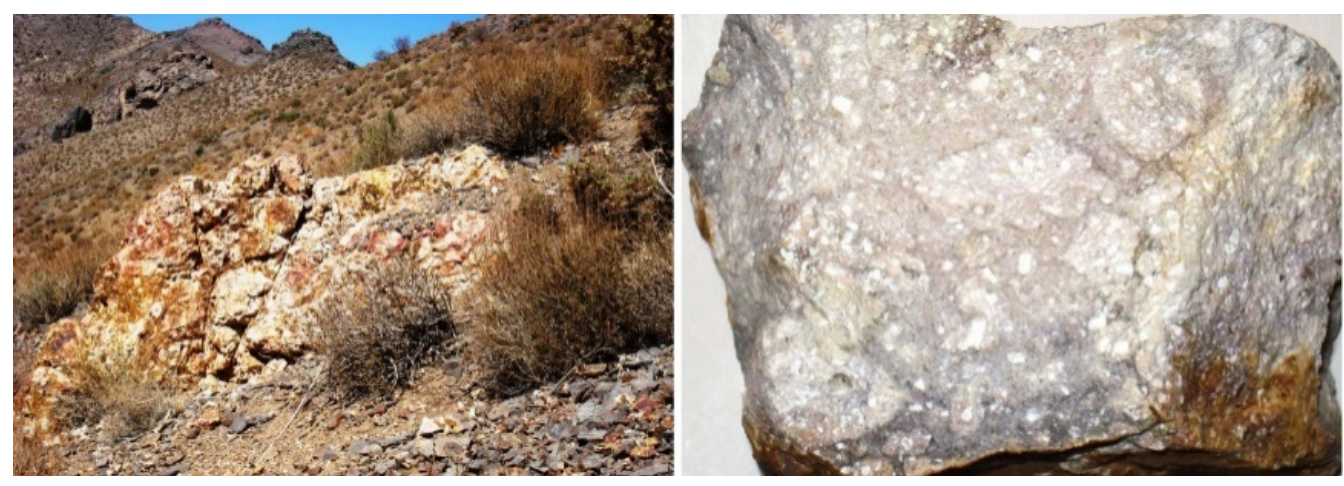

Figure 1. An overview of volcanic rock outcrops across ghaleh-hadi zone and sampling from the area.

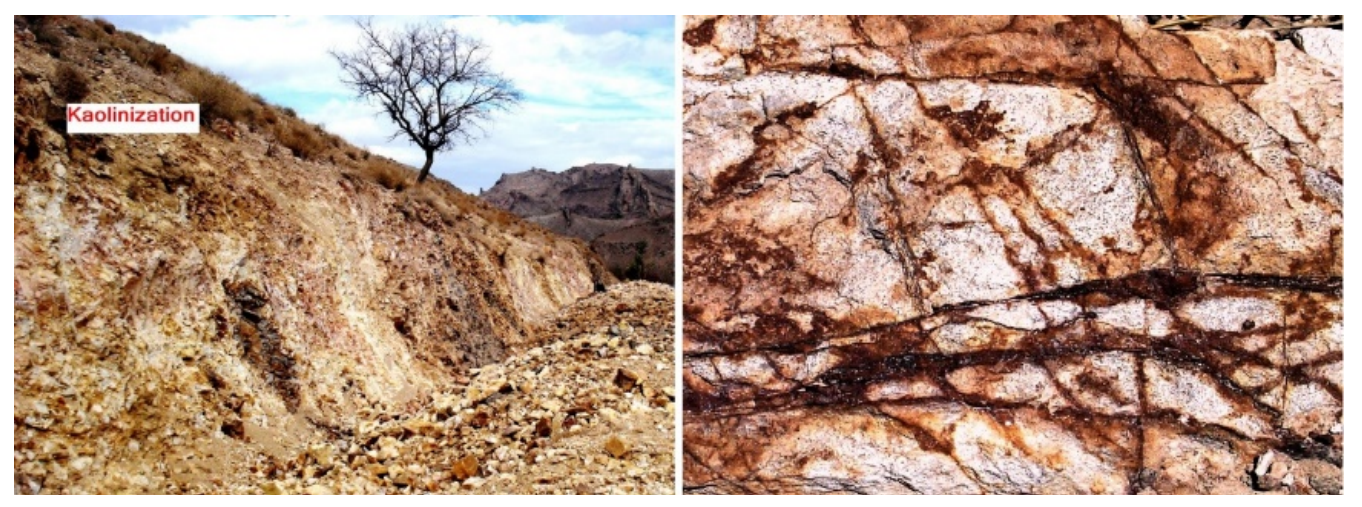

Figure 2. A larger view of the severity of kaolinitation and visible sulfide veinlets in rocks over this area.

Table 1. Frequency values for elements in the above-mentioned sample.

\begin{tabular}{ccccccccccc}
\hline Sample No. & $\mathrm{Au}$ & $\mathrm{Ag}$ & $\mathrm{Cu}$ & $\% \mathrm{Fe}_{2} \mathrm{O}_{3}$ & $\mathrm{Mo}$ & $\mathrm{Pb}$ & $\mathrm{Zn}$ & $\mathrm{W}$ & $\mathrm{As}$ & $\mathrm{Sb}$ \\
\hline Kb.02.ch & 2.20 & 0.20 & 147 & 3.11 & 2.7 & 7 & 91 & 0.75 & 10.30 & 3.21 \\
\hline
\end{tabular}


Kaolinite can be formed in hydrothermal alteration systems. Moreover, it can be observed in the argillic alteration zone and at the border of mineralized regions with high sulphidation. Kaolinite is formed at temperatures between $150^{\circ} \mathrm{C}$ to $200^{\circ} \mathrm{C}$ and horizons close to the ground surface and above the water table where the pressure is low and correlated with argillic alteration zones associated with low-sulphidation epithermal environments. Another environment forming kaolinite involves the timing of supergene alteration.

\subsection{Point N29 37 49.3 E56 3105.5}

It is an example of argillic carbonate alteration. Captured from this location were 3 andesite-porphyry samples, the origin of which can be considered the edge of a volcanic system. What makes this place interesting is the presence of carbonate alteration, where there is extreme transformation into carbonates (calcite-dolomite-siderite) and oxides hydroxides of iron ores. Rocks are fractured under mechanical loads and filled by carbonate (calcitedolomite-siderite). The rock texture has to a certain extent turned into clay minerals. In another sample, transformation into calcite is visible in crystals of feldspar and rock texture. The apak crystas were partly transformed into iron oxides hydroxides where there are visible masses of secondary quartz in the rock as well as a trace of opacity amphibole crystals. With general formula (Ca, Fe, $\mathrm{Mg})\left(\mathrm{CO}_{3}\right)-\mathrm{Ca}(\mathrm{Mg}, \mathrm{Fe})\left(\mathrm{CO}_{3}\right)_{2}$, the carbonates in alteration zones for volcanic sulphide deposits are an important indicator. The principal minerals of this type of alteration include chlorite and pyrite, quartz and sericite (Figure 3).

\subsection{Points N29 36 23.2 E56 2914.4 and N29 36 27.5 E56 2915.7}

An example of argillic alteration is phyllic and albite. This is a spot in the central-western part of Bidkhan. The retrieved sample indicates an extremely altered rock, which is why it was called that name. The feldspars in this sample have turned into sericite and illite minerals. Moreover, the sample indicates severe contamination with hydroxides of iron oxide in the form of both gap-filling veinlets and transformation of apak ores and ferromagnesian minerals into oxide hydroxides of iron (Figure 4).

\subsection{Point N29 38 01.3 E56 3014.0}

An example of advanced argillic alteration would be alunite and silica. Samples were taken from the northern
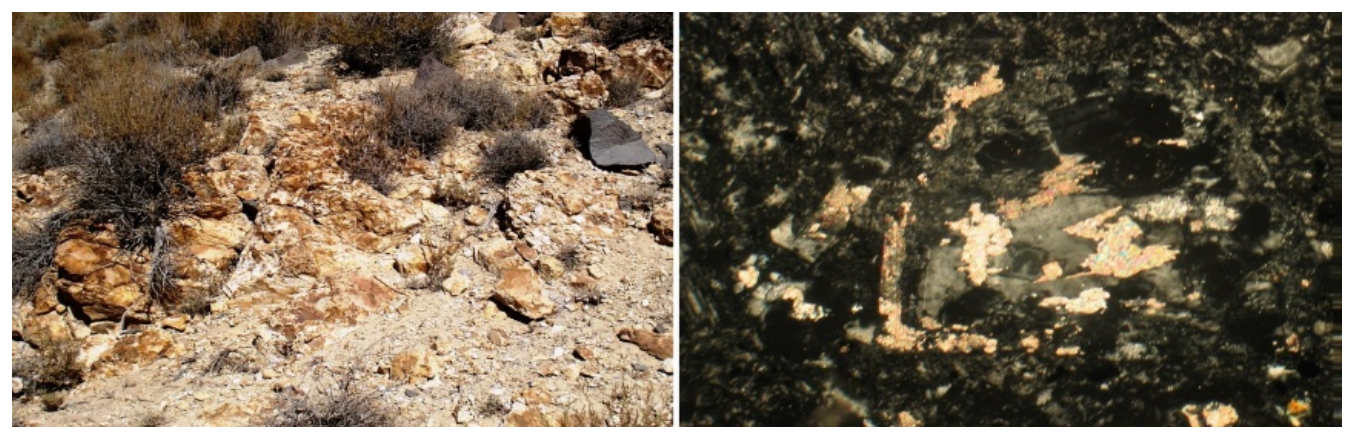

Figure 3. The outcrops of tuffs and andesites and the sample containing argillic-carbonate alteration.

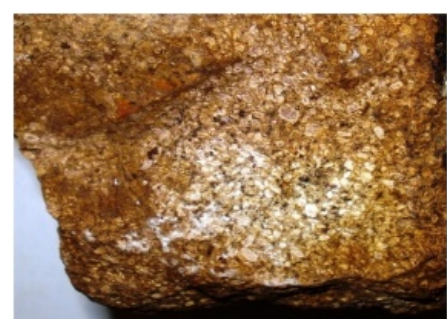

(a)

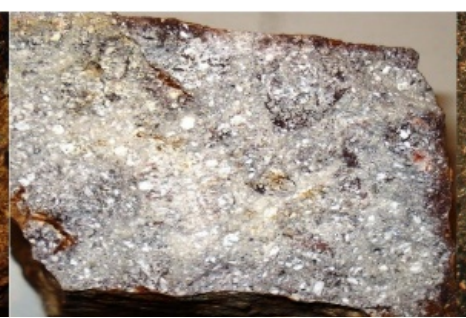

(b)

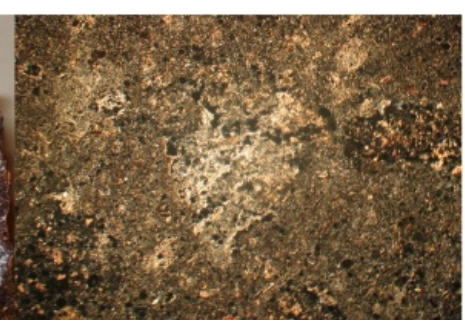

(c)

Figure 4. Picture from left to Right: (a) Presense of 18\% illite-muscovite and albite-altered associated with the porphyry system; (b) It is associated alteration minerals are sericite, illite and tremolite; (c) The tuff has been extremely altered containing clay minerals, oxides and hydroxides of iron and muscovite. 
parts of Bidkhan. This is a tuff rock extremely indicative of silicified alteration and transformation into clay minerals. The secondary minerals in this sample include silica, clay minerals, oxides-hydroxides of iron and lokoksen (Figure 5).

Natroalunite $\mathrm{NaAl}_{3}\left(\mathrm{SO}_{4}\right) 2(\mathrm{OH})$ is one of the minerals from alunite group. The presence of $45 \%$ alunite in this sample is indicative of intense alteration. Alunite is one of the characters of advanced argillic alteration accompanied by mineralizations such as $\mathrm{Cu}$ Porphyry $( \pm \mathrm{Au}, \pm \mathrm{Mo}$ ) and epithermal mineralization with high sulphi-dation. At the landscape covering such alteration, the magmatic $\mathrm{SO}_{2}$ in the presence of water in produces $\mathrm{SH} 2$ and $\mathrm{H}_{2} \mathrm{SO}_{4}$, which are accompanied by $\mathrm{HCl}$ impacting the rocks across the region, causing alteration ranges with advanced alunite-containing argillic. Silicification can be seen in the neighboring regions. In the regions with epithermal advanced argillic alteration or alteration from pickling form at the upper part of the water table caused by condensation and oxidation of $\mathrm{SH} 2$ and reaction with $\mathrm{H}_{2} \mathrm{SO}_{4}$. The argillic alteration zone forms a layer specified by a collection of alunite, kaolinite \pm cristobalite \pm sulfur. The deep fluids in this hydrothermal system may contain neutral-PH chloride waters, which are probably accompanied by low sulphidation mineralization of base metals, or alternatively, acidic sulfate waters with low $\mathrm{PH}$, which are probably associated with associated with high-sulphidation deposits. Near this point at N29 3804.1 E56 30 16.2, there were several samples retrieved for geochemical analysis as presented in the below table, where $\mathrm{Au}$ is measured in ppb, $\mathrm{Fe}_{2} \mathrm{O}_{3}$ in percentage and other elements in ppm (Table 2).

\subsection{Point N29 3811.7 E56 3022.3}

It is an example of silicification where interesting events occurred in the area. An outcrop event is the presence a fault at N $12 \mathrm{E}, 49 \mathrm{SE}$. The major rocky outcrop in this region belongs to intermediate volcanic rocks, which are extremely silicified in reverse across the fault forming a strain approximately 300 meters along and 8 meters wide. There were numerous samples taken from this extremely silicified strain where the texture entails high-density tiny pyrite crystals. There were lithic-vitric tuffs where the entire pyrites were replaced due to supergene alteration by limonite and goethite (Figure 6). This process was so intense that all remained from the pyrites were their platforms.

\subsection{Point N29 36 59.1 E56 3026.4}

It is an example for propylitic and sericite quartz alterations. The sample for this region is a latites quartz where transformation of feldspar crystals from the center into epidote (pistasite and zoezit) and silicificationare visible. Furthermore, the stone texture has partly turned into clay minerals visible in the form of certain feldspar crystals

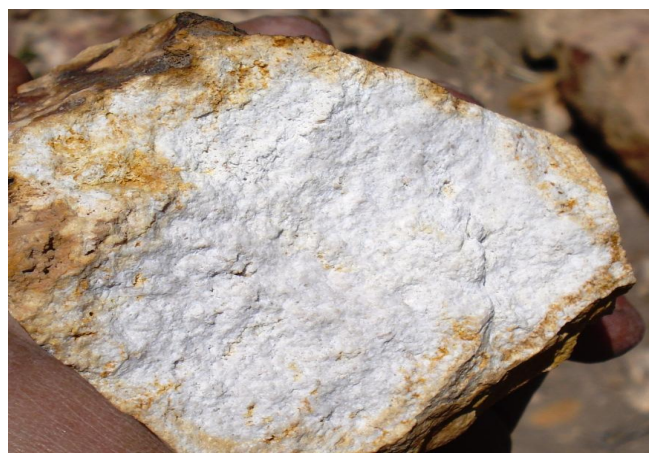

Figure 5. Close view of altered samples.

Table 2. Results of analyzing the retrieved samples.

\begin{tabular}{|c|c|c|c|c|c|c|c|c|c|c|c|c|}
\hline Sample No. & $\mathrm{Au}$ & $\mathrm{Ag}$ & $\mathrm{Cu}$ & $\% \mathrm{Fe}_{2} \mathrm{O}_{3}$ & Mo & $\mathrm{Pb}$ & $\mathrm{Zn}$ & W & As & $\mathrm{Sb}$ & $\mathrm{Bi}$ & $\mathrm{Hg}$ \\
\hline Kb.31-1.ch & 1.6 & 0.11 & 34 & & 20.0 & 9 & 30 & 7.72 & 100 & 0.82 & 0.54 & 0.09 \\
\hline Kb.31-2.ch & 2.0 & 0.30 & 222 & 2.51 & 14.6 & 16 & 62 & 23.00 & 116 & 3.63 & & \\
\hline Kb.73.ch & 2.1 & 0.20 & 45 & 2.34 & 14.6 & 22 & 66 & 20.10 & 109 & 1.92 & & \\
\hline
\end{tabular}




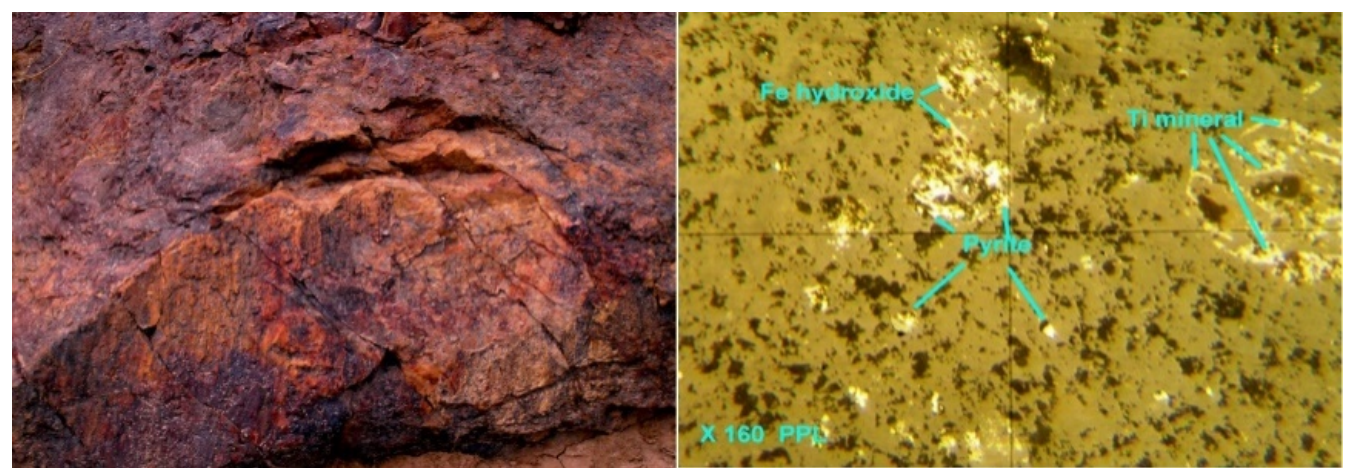

Figure 6. Rocks extreme silicification along the reverse fault and transformation of pyrite into other minerals through alteration.

containing some sericite (Figure 7). The epidote visible in the the volcanic surrounding of intrusive mass is representative of propylitic alteration associated with epithermal systems in connection or intrusive bodies. The epidote is formed in altered volcanic rocks where the temperature of hydrothermal fluid is greater than 230 degrees. Therefore, epidote streams both in close and far distances to the mineralization in porphyry and deep epithermal environments.

Figure 8 is an example of rhyodacite. This rock has been composed of large and to a certain extent altered crystals across a tiny texture. There is an extreme alteration into sericite and muscovite in the rock as the biotite scales have transformed into muscovite and released titan oxides along its cleavages and there is also evident transformation of clay minerals across the rock texture and crystals.

\subsection{The Zone Surrounding N29 3642.8 E56 3025.8}

Is an example of sericitic alteration. Figure 9 is a microgranodiorite with texture porphyry and extremely altered hialomicrogranular. Sericite, muscovite and calcite are mineral products of alteration in this sample. Analysis of the alteration may be confused with propylitic alteration especially when the numerical values of albite and quartz are very high. It should be noted that high levels of these two minerals are in direct correlation with the rock-forming minerals rather than those minerals formed as a result of alteration. Pyrite has the highest frequency of ores by $6 \%$ to $8 \%$ in the sample. The calcopyrite crystals in this sample are not at all associated with other ores found in the sample. Another ore in the sample is galena $\left(\mathrm{PbSO}_{4}\right)$ seen as a stain. The galena in this sample, similar to chalcopyrite, has no association with other metal ores found at the section [1] [2].

\subsection{The Surrounding Area of Point N29 3614.6 E56 2947.7 and N29 3612.6 E56 29 14.2}

It is an example of phyllic and propylitic. For the sample of a microgranodiorite, there is visible mineral change caused by phyllic, sericite and propylitic alterations (Figure 10). Another interesting alteration observed in the region where the sample was retrieved is biotite which has transformed into chlorite and calcite and has transformation released rutile along its cleavages [3] [4].

\subsection{District N29 3536.2 E56 2931.7}

It is an example of propylitic, phyllic, argillic, malachite. (Figure 11) has been named latites. The feldspar crystals in the rocks of this area have turned into a collection of secondary minerals such as sericite, illite and other clay minerals. The amphibole crystals are completely altered their format has mostly been filled by malachite, apak crystals and oxides - hydroxides of iron, chlorite, epidote and titanium oxides. Also visible in some feldspar crystals is malachite [5] [6].

Spanning approximately $500 \mathrm{~m} \times 500 \mathrm{~m}$, the region holds a few types of alterations in the rocks. The point presented above is roughly the center of the area where the phyllic alteration can be seen clearly. At this point, malachitation signs are visible at several points marked on the map with the symbol $\mathrm{Cu}$. In replacement from the center to the surrounding, other alterations such as propylitic and argillic are visible. Although counted as a more common type of alteration in comparison with other zones such as argillic and advanced argillic, the propylitic 


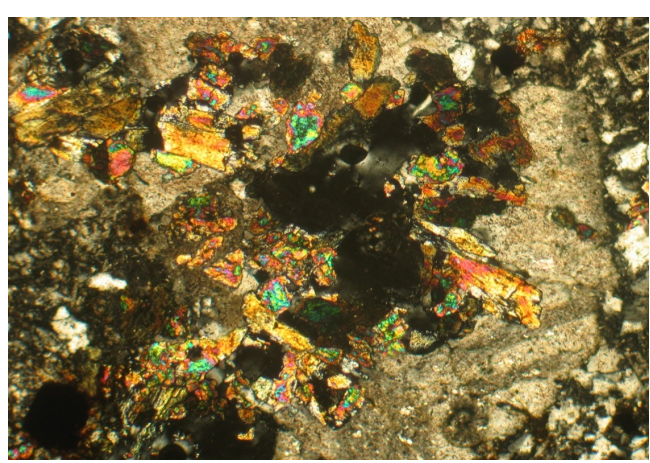

Figure 7. Alteration at microscopic section of epidodited samples.

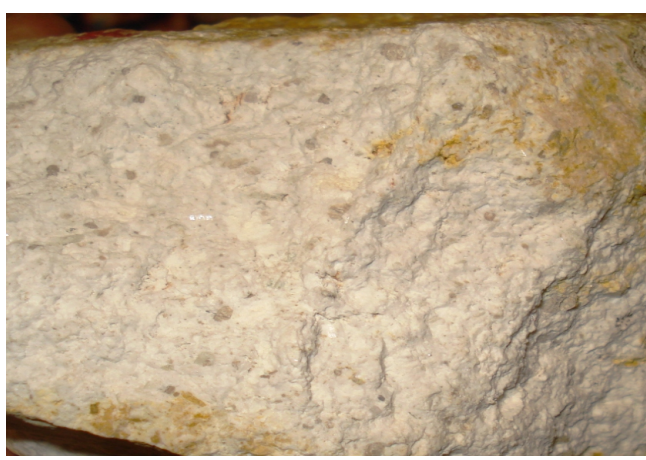

Figure 8. Close-up of rhyodacite sample.

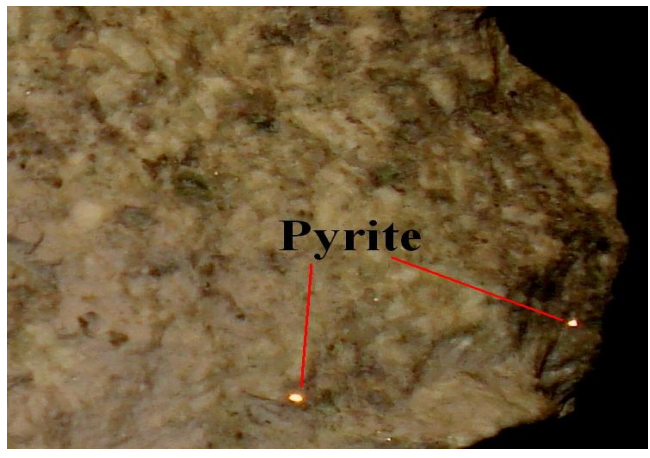

Figure 9. Close-up of sample.

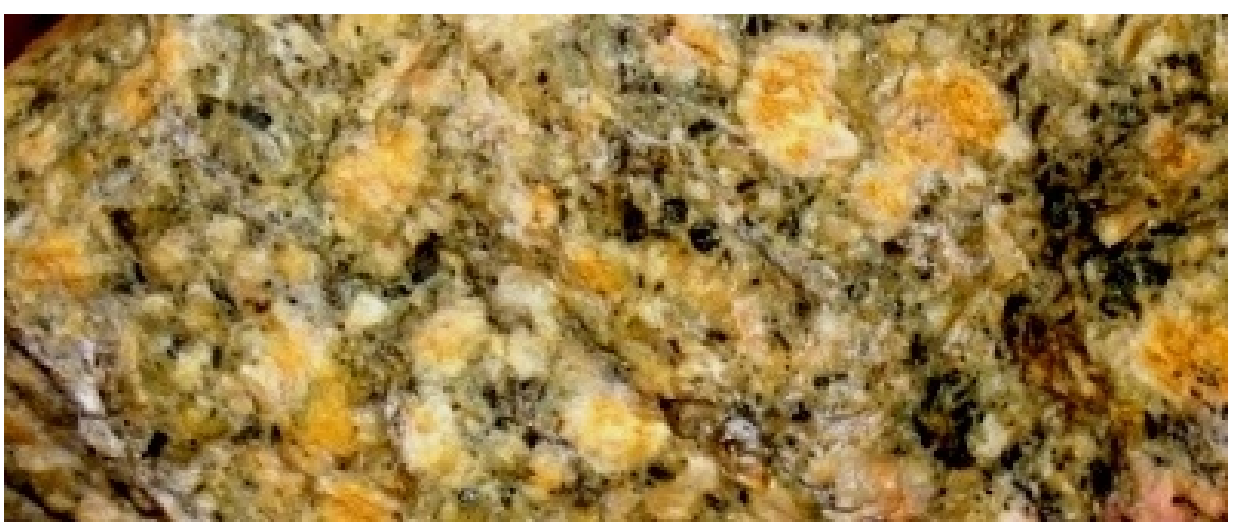

Figure 10. This is an example of latite andesite. 


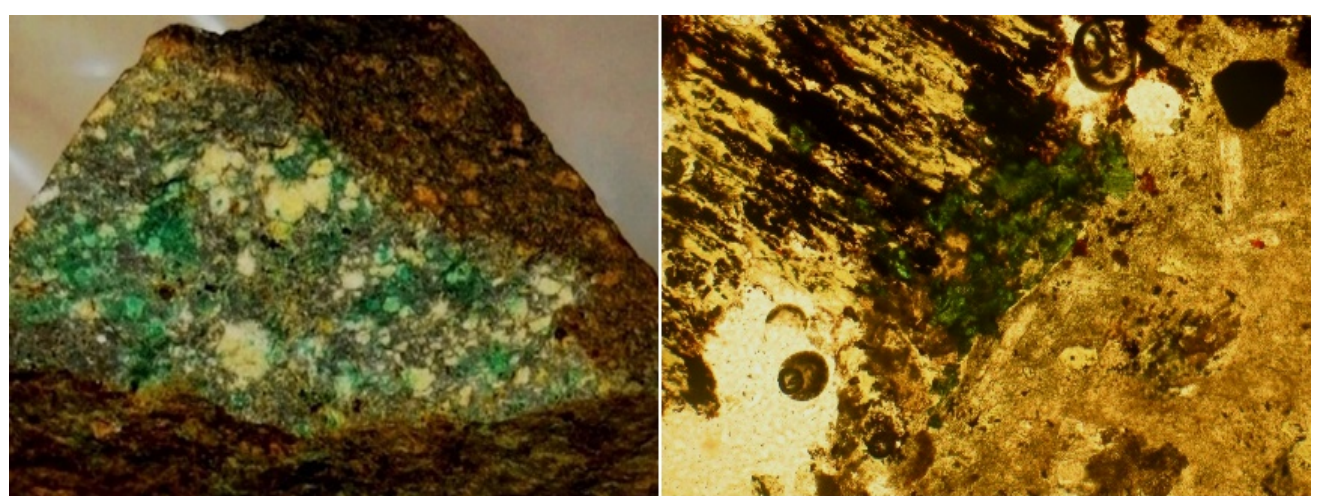

Figure 11. A sample where malachite replaced feldspar and the signs of malachitation.

zone is important since it can represent the discovery area. The propylitic zone in Bidkhan is seen as a band around the central part. As one of the main alterations, the phyllic alteration together with other evidence greatly helps the tracking of mineralization zones and analysis of alteration systems. The phyllic alteration refers to sericitic-quartz-pyrite zone usually located at the upper parts of potassic alteration zone [7] [8].

\subsection{Point N29 3736.5 E56 3110.4}

Is an example of silicification. This part entails the most common form of the effects of tectonic forces, i.e. the fault. In many cases, these faults cannot be revealed or measured. Fortunately, the fault wall signs in this region are completely visible and measurable. The tuff and volcanic outcrops in this region are typically associated with major or minor faults. For example, the heavily altered outcrop seen in Figure 12 is located along a dextral strike-slip fault at N03E, 81SE.

Rutile or $\left(\mathrm{TiO}_{2}\right)$ is one of the ores seen in these samples. Rutile is formed under relatively widespread conditions, one of which is the process of hydrothermal alteration. In such conditions, titanium oxide is found together with ilmenite, ilmenorotile, hematite and magnetite. The results of analyzing the samples retrieved from the spot have been given in Table 3. What is evident in this area is the relationship between structural elements in the alteration zone. At this point, there is a fault around which this alteration has been formed. The fault has provided a channel for the fluids originating from the deeper parts. These fluids experience certain changes all the way from the depth to the surface and eventually led to extreme silicification at the surface outcrops.

In the above table, the value of Au was measured in $\mathrm{Fe}_{2} \mathrm{O}_{3}$, ppb in percentage and other elements in ppm. The transition from depth to surface is tantamount to the passage from a spot under HT-HP to LT-LP. The same thermodynamic changes can propel the magmatic fluids to leave their contents in different thermal-compressive directions (Figure 13).

\subsection{The Potassic Alteration Zone Surrounding the Point N29 3749.3 E56 3105.5 (Ghaleh-Hadi Valley, Northwest of the Region)}

There are extremely altered sub-volcanic rocks and tuffs formed around the spot where samples were retrieved. Moreover, the outcrops across the region host numerous dikes. There are visible advanced argillic and argillic alteration and carbonate rocks in this region. What can be seen as an example in this sample and the rocks over the region is biotite which forms the format of secondary amphibole crystals (Figure 14 and Figure 15) [9] [10].

\subsection{Areas Entailing Evidence of Supergene Alteration}

In many locations, there are signs of supergene zone commonly at the edge of the central part of Bidkhan. For example, Table 4 illustrates a few points and their coordinates, which represent regions containing supergene evidence. There are a large number of such places with evidence of supergene discussed later [11].

\subsection{Area Centered at Point N29 37 36.5 E56 31 10.3}

Silicification can be clearly seen in outcrops of this region. The silica resulted from silicification is crystallized 


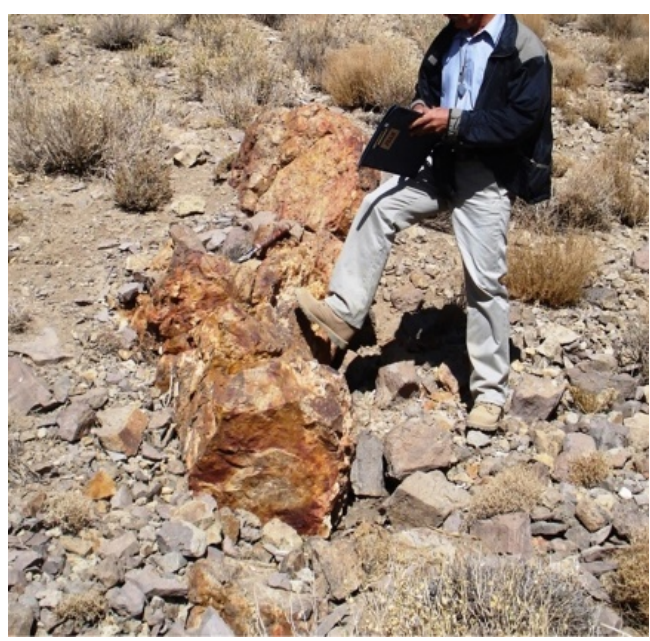

Figure 12. Extremely altered outcrop along a strike-slip fault.

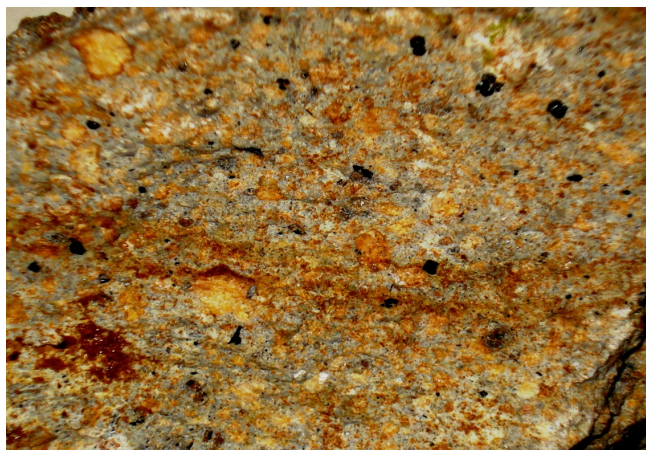

Figure 13. Sign of iron oxides and hydroxides in the rock as products of pyrite oxidation.

Table 3. Results of analysis on samples.

\begin{tabular}{cccccccccccc}
\hline Sample No. & $\mathrm{Au}$ & $\mathrm{Ag}$ & $\mathrm{Cu}$ & $\mathrm{Fe}_{2} \mathrm{O}_{3}$ & $\mathrm{Mo}$ & $\mathrm{Pb}$ & $\mathrm{Zn}$ & $\mathrm{W}$ & $\mathrm{As}$ & $\mathrm{Sb}$ \\
\hline Kb.12.ch & 1.5 & 0.20 & 257 & 3.84 & 10.0 & 15 & 126 & 4.77 & 35.80 & 7.08 \\
Kb.13.ch & 1.6 & 0.80 & 25 & 7.04 & 0.5 & 50 & 61 & 1.22 & 25.60 & 2.34 \\
Kb.14.ch & 1.5 & 2.50 & 76 & 1.68 & 3.9 & 67 & 49 & 15.00 & 30.90 & 83.70 \\
Kb.15.ch & 6.2 & 0.50 & 48 & 4.00 & 15.7 & 30 & 97 & 9.18 & 21.70 & 8.26 \\
Kb.16.ch & 1.6 & 0.20 & 261 & 3.05 & 14.0 & 17 & 60 & 4.29 & 35.50 & 9.19 \\
Kb.18.ch & 2.2 & 0.40 & 36 & 5.19 & 3.7 & 30 & 85 & 8.39 & 187.00 & 5.74 \\
\hline
\end{tabular}

again at the next step influenced by another factor. Part of the silica found in these rocks is amorphous. The petrology of this region covers sub-volcanic and volcanic outcrops, while the metal mineral collection includes pyrite, titanium-containing ores and iron hydroxides. The supergene processes in the environment where the sample was found had replaced most of the pyrite crystals by Limonite (Hydrogoethite) $=\mathrm{HFeO}_{2} \cdot \mathrm{nH}_{2} \mathrm{O}$ and Goethite $=\mathrm{HFeO}_{2}$. Part of hydroxides of iron found in the sample penetrated into the rock from the outside, filling the gaps and fractures. The prominent characteristics of this region are veinlets of iron hydroxide oxide (originated from the oxidation of pyrite) at high density. The veinlets have a thickness of one millimeter to centimeter, and length of several decimeters (Figure 16). 


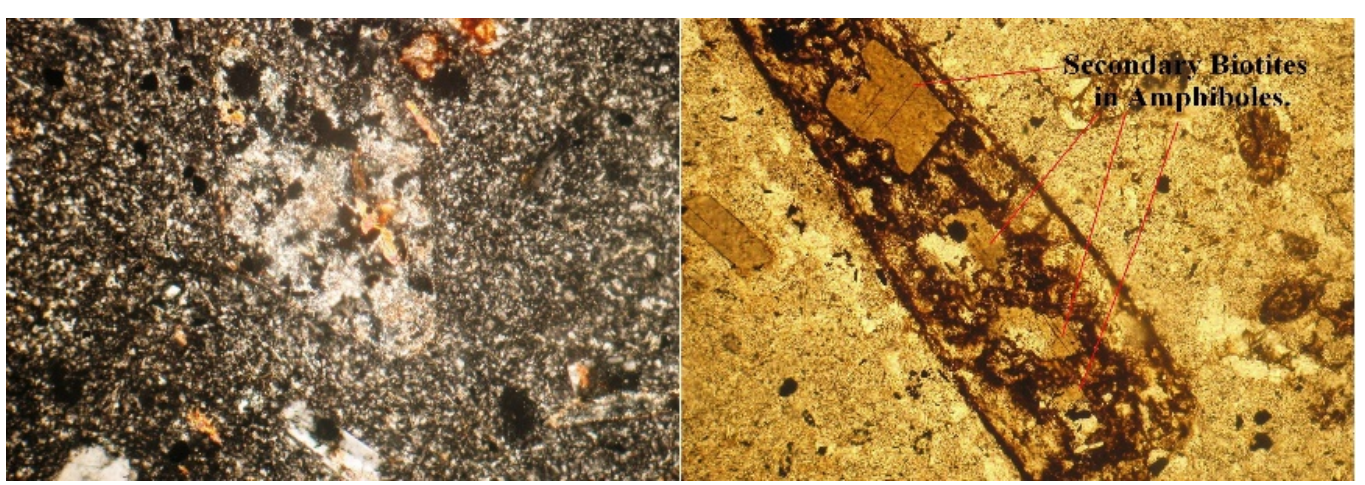

Figure 14. Secondary crystal of biotite grown in amphibole crystals.

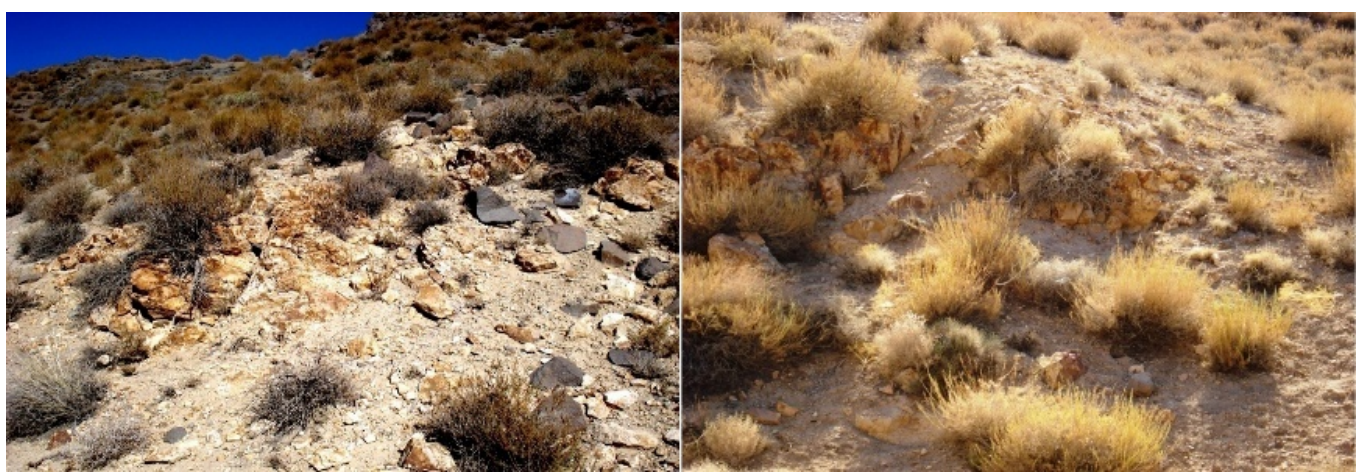

Figure 15. Areas with sericitic, phyllic alterations and outcrops with advanced argillic alteration.
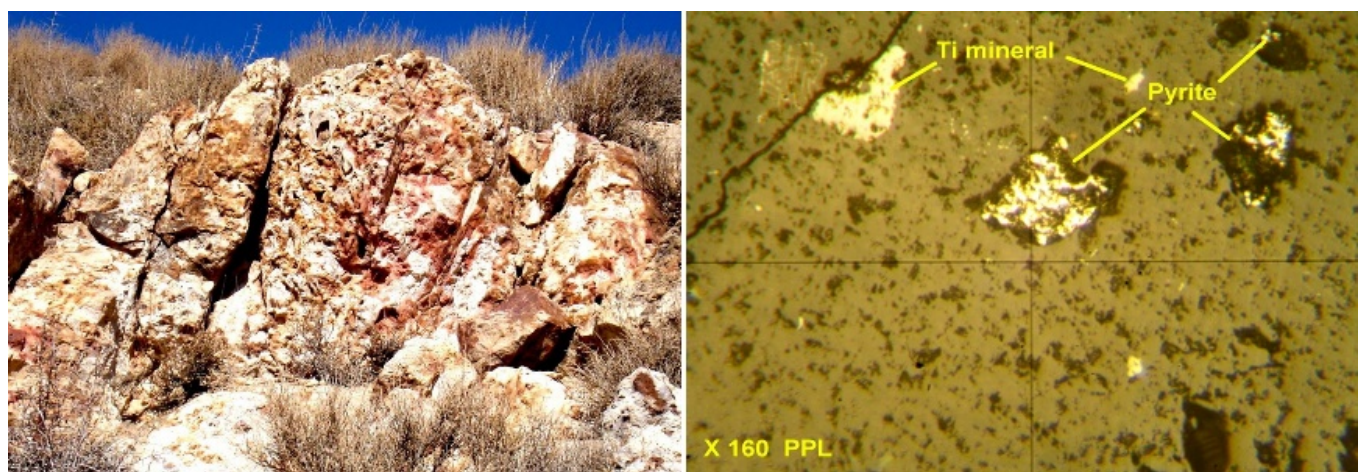

Figure 16. Outcrops of sericite, rock silicification and replacement of pyrite by iron oxide and hydroxide.

Table 4. Areas contaning supergene.

\begin{tabular}{ll}
\hline \multicolumn{2}{c}{ Some Supergene Evidences Coordinate } \\
\hline 1 & N29 3736.5 E56 3110.3 \\
2 & N29 38 12.5 E56 30 22.5 \\
3 & N29 38 21.5 E56 30 24.5 \\
4 & N29 36 19.3 E56 29 03.1 \\
5 & N29 36 42.8 E56 30 25.7 \\
6 & N29 36 15.6 E56 30 48.8 \\
\hline
\end{tabular}




\subsection{The Zone Surrounding N29 3812.5 E56 3022.5}

Outcrops in this region indicate not only silicification but also argilitation as transformation into clay minerals. The main outcrops found across this region have been formed by sub-volcanic and volcanic rocks. The most important ores found in the supergene zone of the region are pyrite, titanium dioxide and iron hydroxides. The pyrites found in this region indicate more the veinlet forms, which have been replaced due to the supergene alteration by limonite and goethite. This process was so intense that all remained from the pyrites were their platforms (Figure 17) [12].

\subsection{Area Centered at Point N29 38 21.5 E56 30 24.5}

Pyrite is the most prominent ore found among the outcrops in this area, which can be abundant. The main mineral components of the rock are made of glass where there visible lithic fragments. One of the components where the phenocrysts are rectangular seemingly feldspars crystals have been completely filled by secondary silica and the rock has been heavily silicified. There are two sets of strains found in the rock, one of which filled by apak and the other filled by epidote. The frequency of apak is about 10 percent and there is some contamination with clay minerals in some areas (Figure 18).

\subsection{Area Centered at Point N29 36 19.3 E56 2903.1}

The intensity of alteration in this area is extremely high and identification of rock typologies and their names is not possible, but field observations and compared with other parts of the region may categorize this area as containing sub-volcanic rocks. The activity of major and minor faults in the central part of Bidkhan, it can be assumed to have been formed by small tectonic blocks put together (Figure 19).

The rocks in this region are extremely altered and their minerals complex has already been transformed into secondary ores such as sericite, muscovite, clay minerals, epidote and oxides-hydroxides of iron (Figure 20). The formats observed in the thin sections of this rock are entirely filled by sericite and muscovite. Moreover, from the crystallography surfaces, it can be identified that they were essentially plagioclase and alkali feldspars. The platform rock has uniformly turned into sericite and clay minerals.

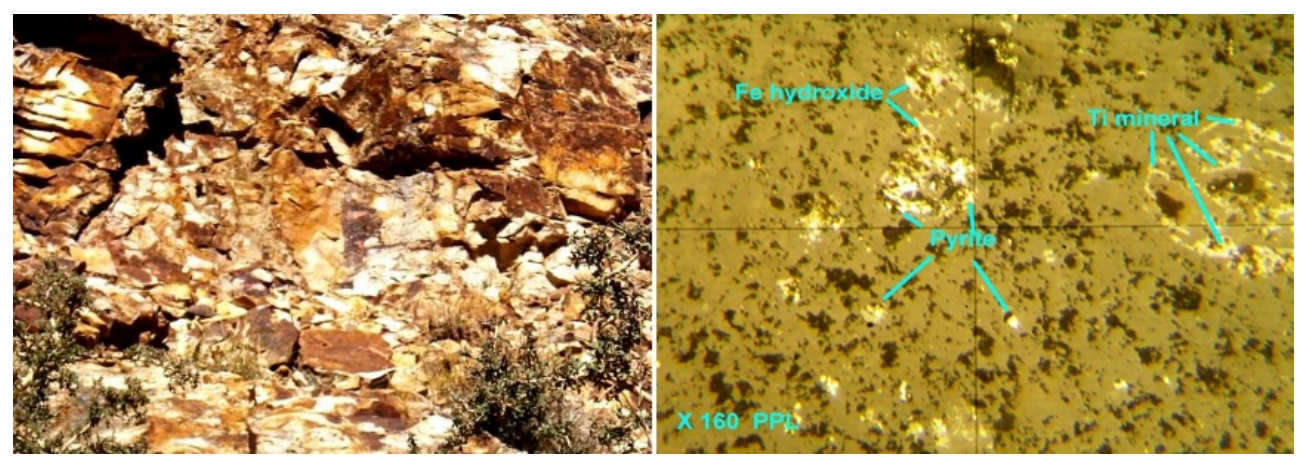

Figure 17. Intensity of rock silicification in the outcrops and replacement of pyrite by secondary minerals.

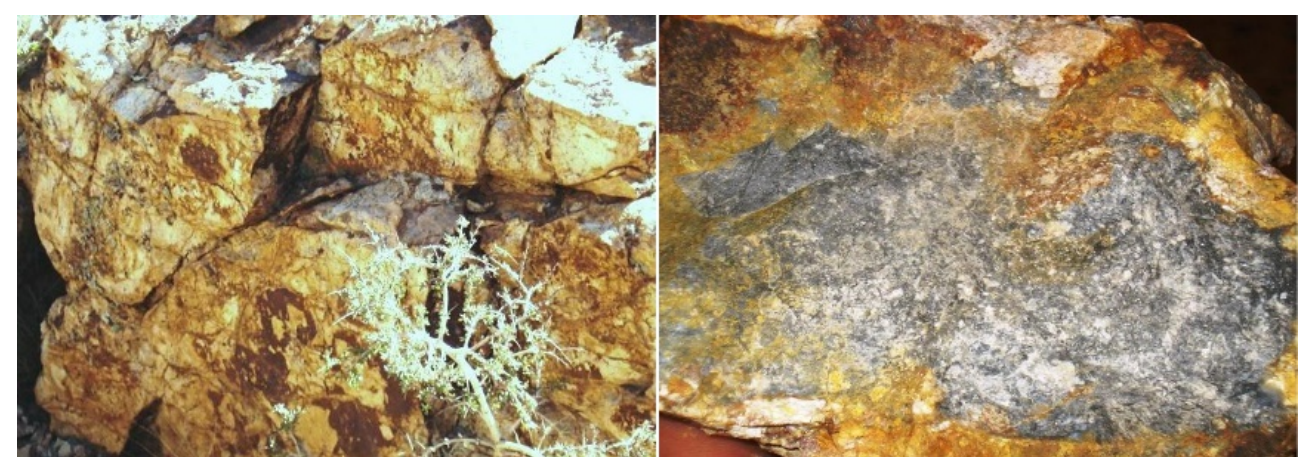

Figure 18. Joint filling in rocks by apak and close-up of the joints filled by apak iron oxide and hydroxide. 


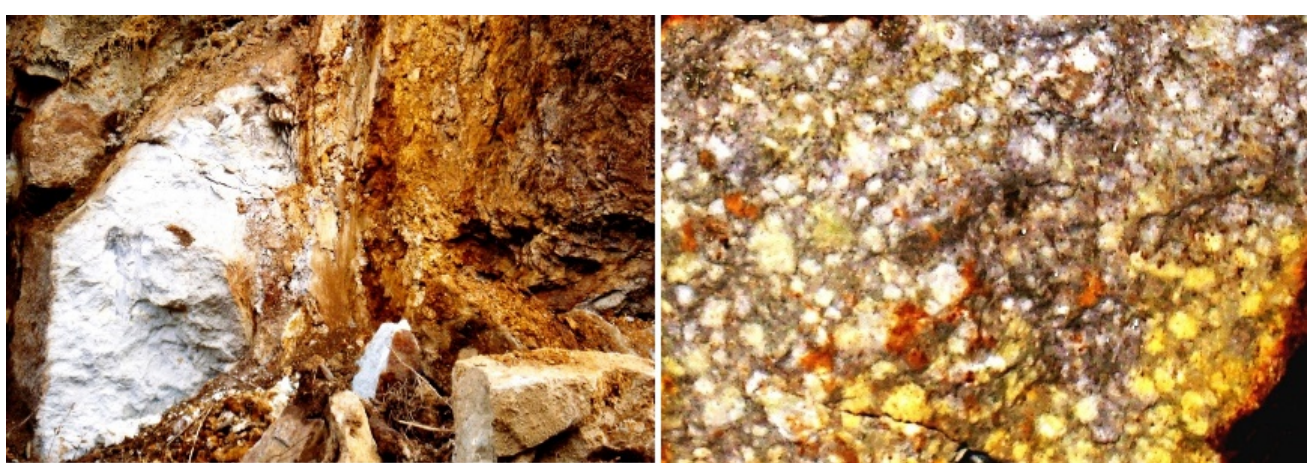

Figure 19. Yellow-red limonite and hematite in the rocks and altered stones and remnants of porphyritic texture.

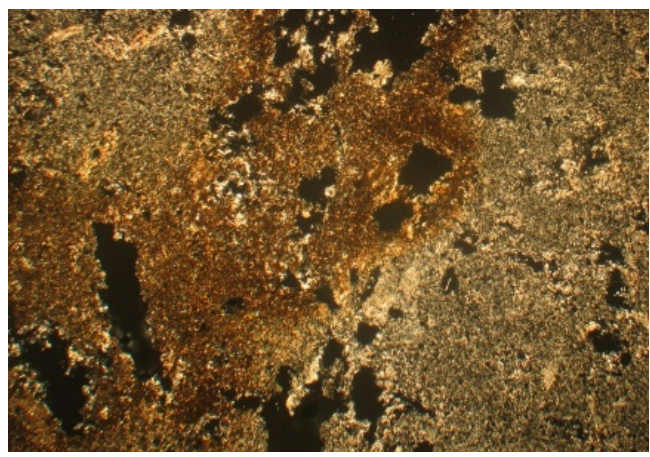

Figure 20. Replacement of secondary minerals due to alteration.

\subsection{Area Centered at Point N29 3642.8 E56 3025.7}

The area is situated in the vicinity of one of the villages at Bidkhan locally called Dehe Bala. The rocks in this region are granitoid and their petrological composition is microgranodiorite. The granitoid outcrops have penetrated as dikes into the outcrops composing the sub-volcanic and volcanic dikes rocks (Figure 21). The dikes in such a petrological composition can be found in many parts of central and peripheral parts of Bidkhan.

The pyrite crystals of this sample are automorph and appear sporadically throughout the entire section. Some of these crystals are $1 \mathrm{~mm}$ in dimensions. The calcopyrites of this sample are not at all associated with other ores found in the sample, and have been established independently in the rock. Another ore found in this sample is galena (Figure 22). The galena in this sample, similar to chalcopyrite, has no association with other metal ores found at the section [13].

\subsection{The Zone Surrounding N29 36 15.6 E56 3048.8}

One of lithologies in the region involves rocks with petrological composition of quartz and monzodiorite. The rocks in this region well reveal the supergene signs. The pyrite found in the rocks of this area are scattered in the cross-section as large as the sample. This pyrite is usually automorph and replaced by supergene through limonite and goetite. Such a replacement begins at the outer margin and then expands toward the center (Figure 23) [14].

\section{Result}

Despite the dominance of volcanic nature over the collection of outcrop units across Bidkhan, there are visible signs of folds in the vast majority of units (Figure 24). The folding phenomenon can be considered as an outcome of stress fields with two different sources. First, these stress fields refer to tectonic forces leading to the formation of structures in the general area of Bardsir. In this respect, the theory of tectonic plates and the opening 


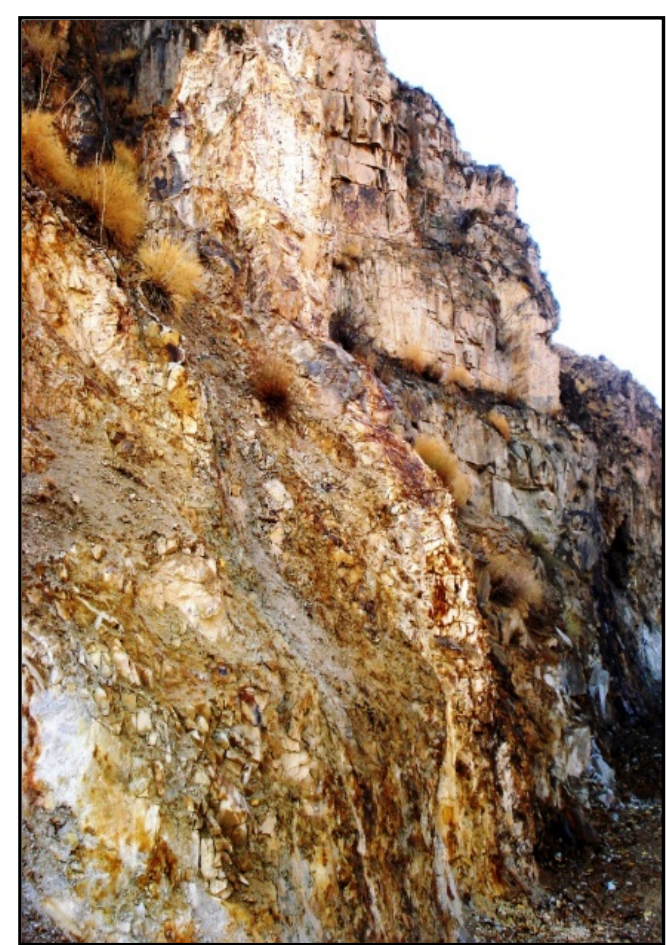

Figure 21. The outcrops of mineralized granodiorite dikes (metal ores found in pyrite, chalcopyrite, galena, and titanium oxide).

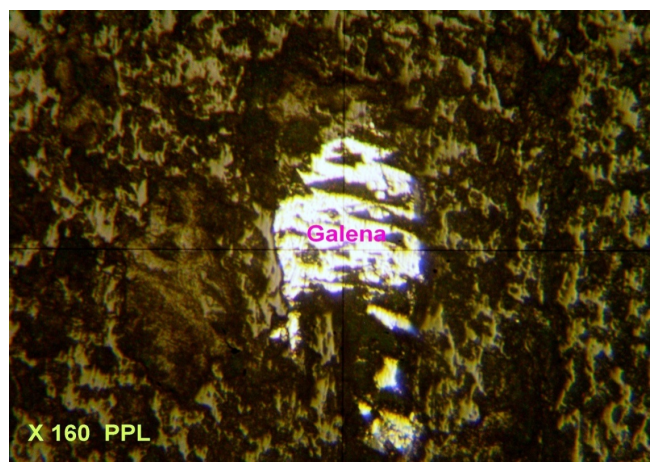

Figure 22. Galena at polished cross-section.

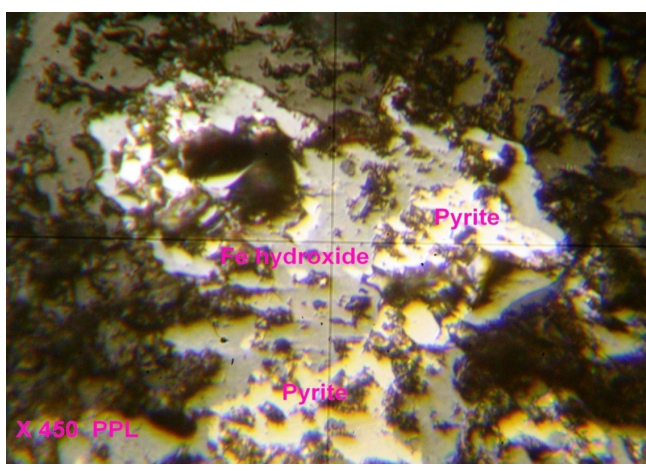

Figure 23. Pyrite replacement from the outer margin toward the center by iron hydroxide. 


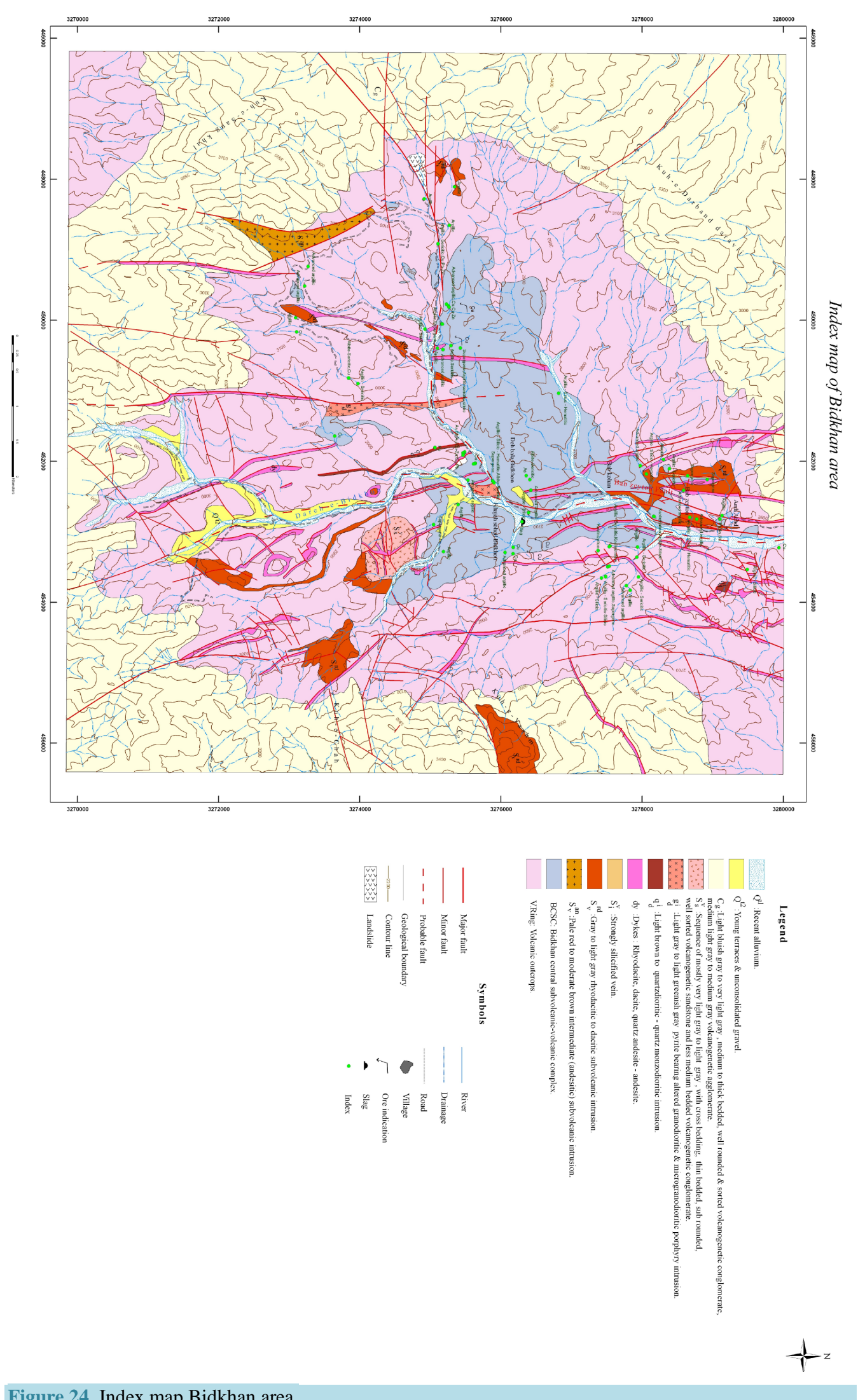

Figure 24. Index map Bidkhan area. 


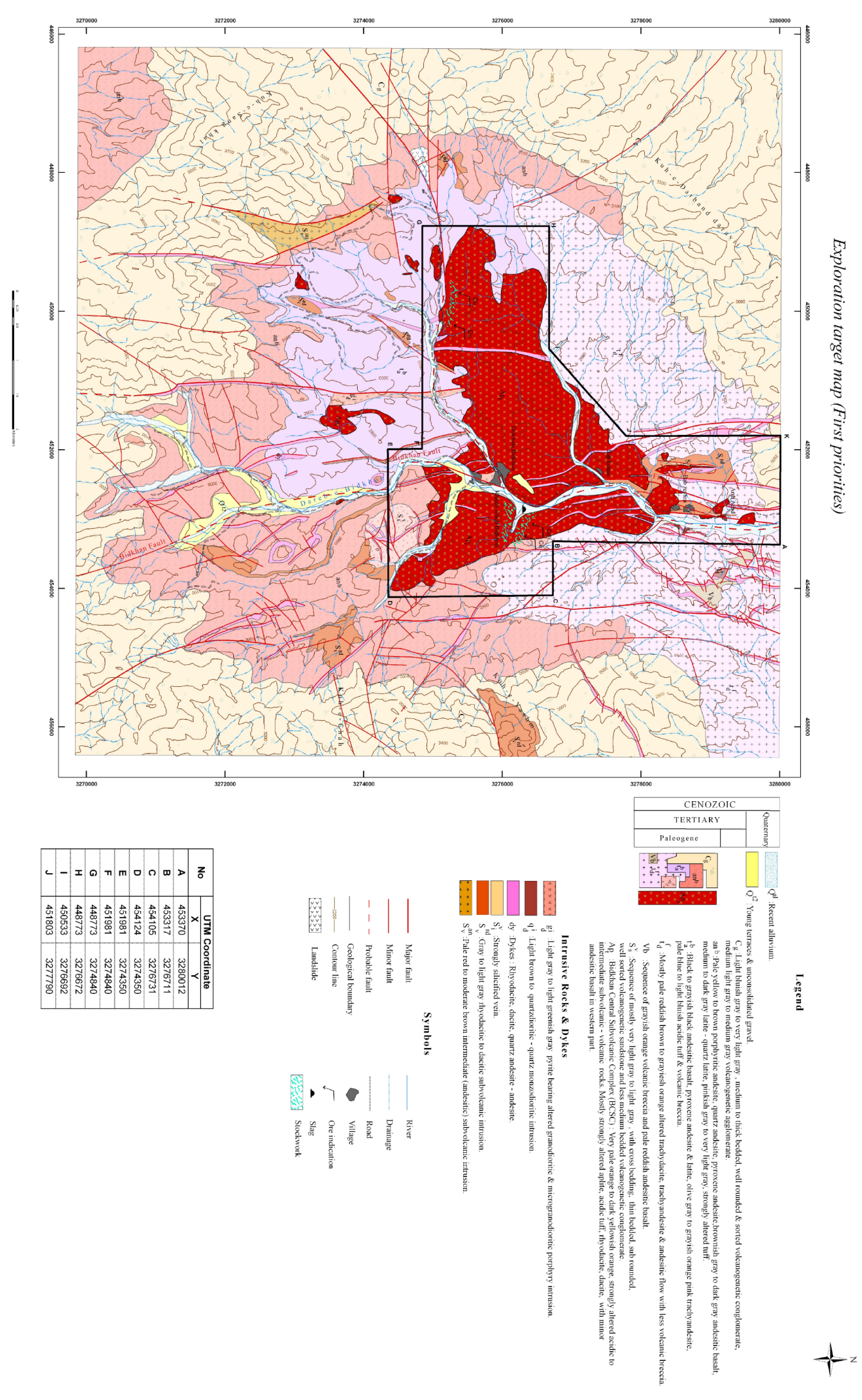

Figure 25. Exploration target map (First priorities). 


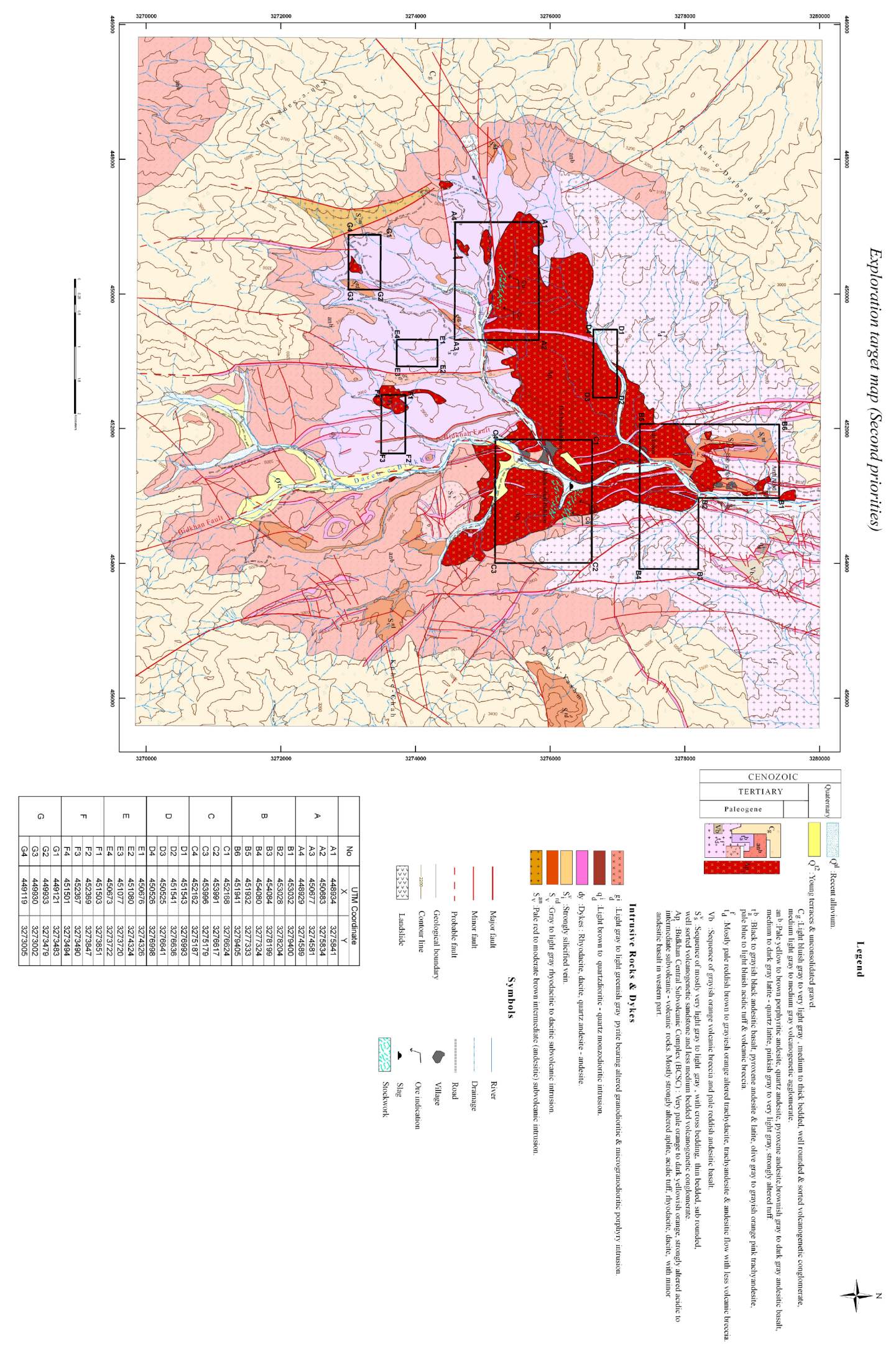

Figure 26. Exploration targeyt map (Second priorities). 
forces and separation of the Arabian plate moving toward the Central Iran plate in the northeast-southwest direction and the process almost perpendicular to the mountains south of Kerman could be the contributing factors. All that visible in Bidkhan can be associated with a porphyry system. This finding is supported by a wide range of data. We should not be misled for determining the general erosion of a field by the possibility that faults with different mechanisms, including reverse faults, could move the lower levels to the top. In addition to a porphyry system in Bidkhan, there is a strain system of very high importance. For that reason, this project involves two priorities for the rest of exploration activities. Priority No. 1 covers an area about 10 square kilometers, which is almost unique to the central part of Bidkhan and its adjacent zones (Figure 25). Nevertheless, priority No. 2 focuses on small scattered areas that are not only extremely altered, but also entail characteristics linking them to the first priority (Figure 26).

\section{References}

[1] Ashofteh, A. and Adib, A. (2014) Primitive Studies for Copper Deposit in Bidkhan Copper Mine with Regards to Wide Survey of Altered Areas and Mineral Indexes. Journal of Middle East Applied Science and Technology, 4, 86-90.

[2] Feizi, F. and Ashofteh, A. (2014) Area Exploration Takhte Soleiman Based on Geophysical and Satellite Imagery. Journal of Middle East Applied Science and Technology, 3, 414-417.

[3] Keshavarzi, R., Esmaili, D., Rezaei Kahkhaei, M., Asghar Mokhtari, M. and Jabari, R. (2014) Petrology, Geochemistry and Tectonomagmatic Setting of Neshveh Intrusion (NW Saveh). Open Journal of Geology, 4, 177-189.

[4] VaeziNejad, S., Tofigh, M. and Marandi, S. (2011) Zonation and Prediction of Land Subsidence (Case Study-Kerman, Iran). International Journal of Geosciences, 2, 102-110. http://dx.doi.org/10.4236/ijg.2011.22011

[5] Jafari, H. and Yazdi, A. (2014) Radioactive Anomalies in 1:50000 Dehbakri Sheet, South of Kerman Province, Iran. Open Journal of Geology, 4, 399-405. http://dx.doi.org/10.4236/ojg.2014.48031

[6] Sabok Khiz, H., Memar Koche Bagh, A. and Hekmatian, M. (2014) Area Exploration Based on Airborne Radiometric Geophysical Data by Surfer Software at Rizab (The South East of Ardakan). J. Bio. Env. Sci, 6, 761-767. http://dx.doi.org/10.4236/ojg.2014.48031

[7] Rothery, D.A. (2010) Teach Yourself Geology. 4th Edition, Hodder and Stoughton, 288 p. [Covers All of the Basics and Is Useful As Either a Primer or a Refresher].

[8] Stanley, S. (2005) Earth System History , W. H. Freeman \& Co. , 567 pp. [Accessible look at the Earth as a system. Extensively illustrated in full colour.

[9] Compton, R.A. (1985) Geology in the Field. John Wiley \& Sons, 398 p. [Comprehensive But Dense Black and White Book on Basic Geology and Field Techniques. Replacement of Compton’ s Manual of Field Geology (1962)]

[10] Freeman, T. (1999) Procedures in Field Geology. Blackwell Science, 93 p. [Pocket Sized, Black and White Book Covering Mainly Mapping Techniques, with Particular Emphasis on Compass Clinometer and Trigonometric Solutions for Recording the Geometry of Geological Features]

[11] Maley, T.S. (2005) Field Geology Illustrated. Mineral Land Publications, 704 p. [Book Illustrating Geological Features and Terms through Hundreds of Clear Black and White Photographs and Line Drawings]

[12] Backer, H.D., Ed. (1997) Wilderness First Aid: Emergency Care for Remote Locations. Jones and Bartlett Publishers, $350 \mathrm{p}$.

[13] Bagshaw, C. (2006) The Ultimate Hillwalking Skills Handbook. David and Charles, 160 p. [Guide to Hillwalking that covers Matters which Are Directly Transferable to Geological Fieldwork, Including Fitness, Navigation, Firstaid, Clothing, Weather, etc.]

[14] Duff, J. and Gormly, P. (2007) Pocket First Aid and Wilderness Medicine. Cicerone Press, 247 p. 